\title{
Drug compliance and the elderly: who is publishing, where, and when?
}

\author{
Cumprimento da prescrição medicamentosa \\ por idosos: quem, onde e quando está \\ publicando?
}

Jorge Juarez Vieira Teixeira 1

Fernando Lefèvre 1

Lia Lusitana Cardoso de Castro 2

Aracy Witt de Pinho Spínola 1

\footnotetext{
1 Department of Practice in Public Health, University of São Paulo, School of Public Health.

Av. Dr. Arnaldo 715 , São Paulo, SP 01246-904, Brazil. jorgetei@usp.br

2 Health Sciences Center Mato Grosso do Sul Federal University Foundation.

Av. Senador Filinto Muller 1480, Campo Grande, $M S$ 79074-460, Brazil. cimufms@nin.ufms.br
}

\begin{abstract}
Population aging has occurred in a rather heterogeneous way worldwide. The increasing size of the elder age group highlights various health-related problems for the elderly. One such issue is non-compliance with drug prescriptions, a potential source of serious, even lifethreatening problems for the patient. The authors have proposed to identify and rank countries that develop research on drug compliance among the elderly, relevant periodicals, and the frequency articles were published between January 1987 and December 1997. A descriptive study was carried out on the basis of a bibliographical review. Three databases were surveyed: MEDLINE, SOCIOFILE e LILACS. The sample included 440 articles, limited to the behavioral sphere. The number of periodicals recorded was 255, varying from one to ten articles. The number of articles published during the study period varied from 23 in 1987 to 49 in 1992, dropping to 29 in 1997. Frequency of the number of articles/year was erratic up to 1992, leveling off from 1993 on at more than double the baseline figure. The authors emphasize the need for developing multi-focused research worldwide.
\end{abstract}

Key words Compliance; Drug Prescription; Elderly; Bibliographical Research

Resumo O envelhecimento populacional no mundo vem ocorrendo de forma heterogênea. $O$ crescimento desta população torna evidentes vários problemas relativos à sua saúde. Dentre eles, o não-seguimento da prescrição medicamentosa pode ter sérias conseqüencias para o paciente, até mesmo risco de vida. Os autores se propuseram a identificar e hierarquizar os países que desenvolvem pesquisas nessa área, os periódicos que as publicam e a freqüência dessas publicações de janeiro de 1987 a dezembro de 1997. Realizou-se um estudo descritivo a partir de uma pesquisa bibliográfica. Para o levantamento, foram utilizadas três bases de dados: MEDLINE, SOCIOFILE e LILACS. A amostra foi constituída de 440 publicações, restritas ao âmbito comportamental. O número de periódicos listados foi de 255, com variação de uma a dez publicações. $O$ número de publicações variou de 23, em 1987, 49, em 1992, até 29 em 1997. A freqüência do número de publicações/ano é errática até 1992, estabilizando-se a partir de 1993, com patamar superior ao dobro do inicial. Enfatiza-se a necessidade de que os pesquisadores da área em todos os países desenvolvam investigações multicêntricas.

Palavras-chave Cumprimento; Prescrição de Medicamentos; Idoso; Pesquisa Bibliográfica 


\section{Introduction}

Population aging has occurred in a heterogeneous way around the world. Both in industrialized European countries and the United States, the demographic transition has taken place slowly and gradually. For various decades or almost two centuries in some cases, a slow drop in the mortality rate and a gradual decrease in the birth rate have been observed. The trend in both these rates was instrumental for causing a slow but steady shift in the proportions of elderly and youth in the population of those countries, with more elderly and fewer youth (Laurenti, 1990).

Over the last five decades, the Brazilian demographic revolution has been marked by changes in the levels of mortality and fecundity from 1940 on, since international migration has not had the same impact as before. Such transitions have directly and significantly affected the population's age structure (Berquó, 1996).

In 1991, Brazil's elderly totaled 10,722,705 individuals, or $7.3 \%$ of the country's total population. Life expectancy at birth was 62.98 years for men and 69.34 for women. Forecasts for the year 2020 see an increase of $13.6 \%(27,173,600$ inhabitants) in this age group and a life expectancy at birth of 72.82 years for men and 78.31 for women (IBGE, 1996).

The growth of the aging population poses various health-related issues. Among them, non-compliance with drug prescription is identified as a potentially life-threatening problem (Stewart \& Cluff, 1972). In addition, physiological, pharmacological, and pharmacokinetic changes in old age (Gainsborough \& Powell-Jackson, 1990; Williams \& Lowenthal, 1992; Offerhaus, 1997) contribute to an increase in the incidence of adverse reactions (Gryfe \& Gryfe, 1984; Frattura et al., 1989; Lee, 1996) associated with the absence of both a health education process (OMS, 1994) and a pharmacotherapeutic follow-up, with potentially serious consequences for the patient. This is a complex and multidimensional problem that merits participation by all segments of society involved with drugs.

According to an important meta-analysis conducted in the United States, an average of $5.3 \%$ of hospital admissions were linked to non-compliance with prescribed medication, at a direct hospital cost of more than US\$8 billion in 1986. When indirect costs were included, estimated expenses totaled US $\$ 25$ billion (Sullivan et al., 1990) and according to one study may have topped US\$100 billion (Coons et al., 1994). With increasing numbers of efficacious self-administered treatments, there is an evident need for better understanding and management of non-compliance, including various combinations of more convenient care, information, counseling, reminders, self-monitoring, reinforcement, family therapy, and other forms of additional supervision or attention. Even the most effective interventions did not lead to substantial improvements in compliance (Haynes et al., 1996).

Drug-related morbidity and mortality in the United States have been identified as the source of an annual cost estimated at more than US $\$ 76.6$ billion in ambulatory care. Most of these funds were spent on drug-related hospitalizations, with an estimated 8.76 million admissions, at an annual cost of US $\$ 47.4$ billion, representing approximately $62.0 \%$ of the total cost. According to the model proposed by the authors, $28.2 \%$ of the total 31.1 million hospital admissions in 1992 resulted from drug-related mortality and morbidity. The 1994 estimate for personal expenses with drug prescriptions was over US $\$ 73$ billion. Recent literature points to a substantial cost associated with inappropriate use of drugs, that can be even higher than the expenses incurred with the drug treatment itself (Johnson \& Bootman, 1995).

Prevalence of non-compliance with drug treatment has raised questions related to the effect of this variable in clinical trials for new drugs. Despite the numerous controls used in such trials, difficulties associated with treatment non-compliance can hamper the determination of true efficacy and toxicity rates for given drugs (Benet, 1997).

The present study stemmed from the need for a literature survey as part of a larger international study on compliance with prescribed medication, focusing on specific databases. The authors proposed to identify and rank countries developing research on drug compliance by the elderly, periodicals covering such research, and the frequency with which these publications were issued from January 1987 to December 1997. International scientific production on this issue was considered particularly relevant in light of the rapid growth of the elderly population.

Prescription compliance is defined here as the level at which the patient's individual behavior corresponds exactly to the physician's recommendation, making effective what was outlined or prescribed (Haynes, 1979).

In this study, behavior is defined as an individual's set of attitudes and reactions towards drug prescription within his/her social milieu. 


\section{Methodology}

A descriptive study was conducted based on a literature review. Data collection took place at the Center for Information and Reference, part of the Library of the School of Public Health at the University of São Paulo, and at the Regional Library of Medicine/Pan Americam Health Organization (PAHO)/Federal University of São Paulo, from February 16, 1998 to February 20, 1998.

The following databases were researched from January 1987 to December 1997: 1) MEDLINE, 2) SOCIOFILE, and 3) LILACS, 30th edition.

The code language used for conducting the survey employed the following strategy: 1) MEDLINE, descriptors: drug* in MESH and $p a-$ tient-compliance/all subheading and aged in MESH, with 872 articles. 2) SOCIOFILE, descriptors - medications* in DE and treatmentcompliance in DE and elderly in DE, with 8 articles. 3) LILACS, free-term - P/d (year of publication) and idos\$ and medic\$, with 362 articles.

The initial sample consisted of 1,242 articles. The articles were selected on the basis of their behavioral focus. The final sample was thus reduced, including only 440 articles. In the present study, a country had to have published a minimum of five articles in order to be considered in the analysis. As for the periodicals, a country had to have published a minimum of four articles in the course of the 12year study period.
The study material included scientific articles issued by national and international journals.

Information on the databases (USP/FSP, 1997): 1) MEDLINE - issued by the National Library of Medicine, USA. Contents cover bibliographical references and abstracts on health and related sciences issued in periodicals. Period: from 1966 forward. Updated monthly. 2) SOCIOFILE - compiled by Sociological Abstracts Inc. Includes bibliographical references and abstracts on sociology and related disciplines, including doctoral theses. Period: from 1974 forward. Updated every four months. 3) LILACS (Latin-American Literature on Social Sciences). Issued by BIREME (Regional Library of Medicine/OPS)/PAHO. Covers both conventional and non-conventional literature on health sciences produced in Latin America and the Caribbean. Period: from 1980 forward. Updated quarterly.

\section{Results}

The databases analyzed in this study cover a major portion of the countries publishing articles on the issue of drug compliance worldwide.

Figure 1 presents the sample universe of research containing the countries that publish relevant articles on drug compliance according to the databases. In this research, publications

\section{Figure 1}

Number of publications dealing with compliance with drug prescription by the elderly, according to the MEDLINE, SOCIOFILE and LILACS databases, by country, from 1/1987 to 12/1997.

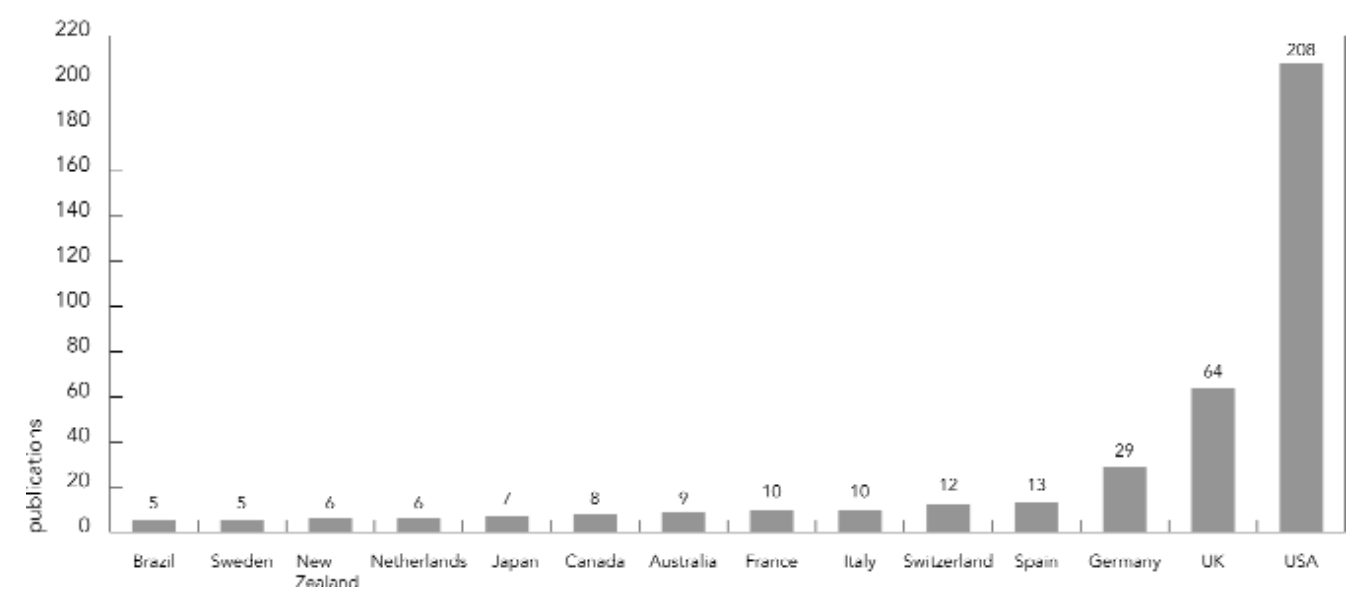


dealing with drug compliance by the elderly were located in 40 countries. Brazil had one article on MEDLINE and four in LILACS. New Zealand and the Netherlands had six articles each. UK (United Kingdom) had 64 articles, and the United States had the largest number of articles, with 201 on MEDLINE and seven in SOCIOFILE. The abbreviation USSR appears in this research because articles published by the Commonwealth of Independent States were issued up to 1990 at the latest.

The total number of periodicals was 255 for the three databases, varying from one to ten articles. As can be seen in Figure 2, the Journal of the American Geriatrics Society is the one with the largest number of articles (ten), or an average of one article/year. Considering the large number of periodicals, we chose to reduce the list for reasons of space. Therefore, only the periodicals that had published a minimum of four articles in the 12-year study period were listed.

Note in Figure 3 that in 1987 there were 23 articles quoted in the three databases. From there on the number of articles increased until 1990. In 1991, there was a slight drop in the number of articles published. The largest increase in the number of articles occurred in 1992; however, from there on the number lev- eled off, with few fluctuations until 1996. Finally, in 1997 the databases showed fewer articles as compared to 1988 and 1996. The year 1997 was closer to 1987 in terms of the number of articles.

For LILACS, Brazil had four articles, followed by Chile, Argentina, Mexico, and Jamaica, with one each.

For SOCIOFILE, the articles published were by North American and European authors.

\section{Discussion}

The main advantage of performing a literature review using databases is that it allows researchers to obtain broader coverage than through a direct search (Gil, 1994). In this kind of search, there are limits that cannot be overlooked in an approach to scientific production using the indicator published article. But one must also recognize that even with some limitations, the indicator published article constitutes material with challenging and stimulating potential for the scientific research (Narvai, 1997).

In the LILACS database, when the "compliance or adhesion or adherence and elderly and drug" strategy was employed, no article

Figure 2

Number of publications dealing with compliance with drug prescription by the elderly, according to the periodical

in the MEDLINE, SOCIOFILE and, LILACS databases, at the international level, from 1/1987 to 12/1997.

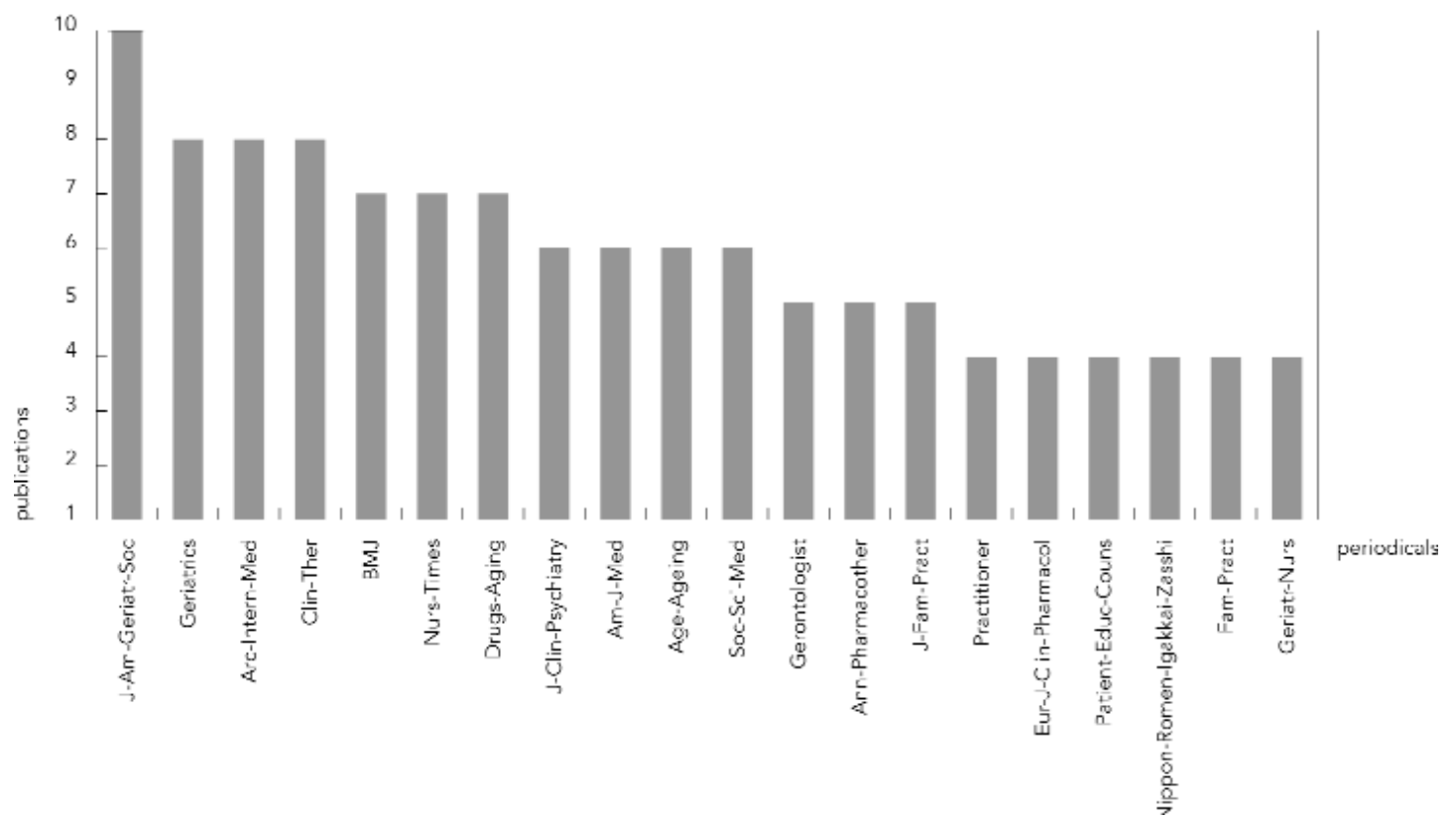


emerged. Therefore, the option was to use the strategy previously described in order to discover the largest possible number of published articles dealing with drugs and the elderly.

The LILACS database showed some limitations, leading us to be concerned and wary of stating whether a given matter had already been the object of study or whether a given researcher had already published another article. The desired reliability pertaining to a given theme is thus disturbed, generating doubts, as described below:

1) It uses many descriptors for a given theme, causing some uncertainty.

2) There is no way for one to know whether a theme has already been the object of study or whether the journals indexed had still not been registered in the base, causing a shift in time due to a lack of sequence.

3) One is always at risk when stating that a bibliographical survey reflects the actual volume of publications in a country, as mentioned above.

Both the MEDLINE and SOCIOFILE databases provide greater security when one aims to locate a given article based on publication in a periodical, registration in CD-ROM, and the period in which it was published.

\section{Conclusion}

According to this study, frequency in the number of articles published annually on drug compliance displays an erratic pattern up to 1992 and levels off from 1993 on at a level almost double the baseline. As for 1997, we believe that many articles have still not been recorded, and thus that the final number will likely increase. The search also points to more extensive scientific production on this theme in the developed countries. We believe that this is due to researchers' need for and interest in scientific production on this theme, as well as to the availability of resources in these countries in their search for an adequate drug compliance profile. In developed countries like the United States, England, Germany, and France, the onset of the aging process has occurred more slowly and earlier than in Brazil. Articles were found in specific periodicals, such as the following: The Gerontologist, Age and Ageing, Drugs Aging, Geriatrics, The Journal of the American Geriatrics Society, etc; they were also found in non-specific periodicals, such as: Social Science \& Medicine, British Medical Journal, Clinical Therapeutics, Archives of Internal Medicine, etc.
Based on the above data, one is entitled to state that the production of scientific articles focusing on drug compliance, especially in Brazil, is still limited. Only one study was located in MEDLINE and SOCIOFILE. Four articles were found in LILACS. This leads one to conclude that the development of research is reflected by what has been published. This might demonstrate the limited importance ascribed to the theme by researchers and/or research institutions. On the other hand, this could indicate that researchers are producing more than what was unearthed by the literature search, but that they are not being published by the databases consulted here, or that they may be producing more than what was located in LILACS, but that due to the delay in recording in the indexed periodicals, one is left with the misleading impression that researchers consider the issue of drug compliance less important. Could this be true?

Finally, we emphasize the need for multifocused studies by international researchers in this area, with the purpose of establishing a profile closer to reality.

\section{Figure 3}

Number of publications dealing with compliance with drug prescription by the elderly, according to the databases, at the international level, from $1 / 1987$ to $12 / 1997$.

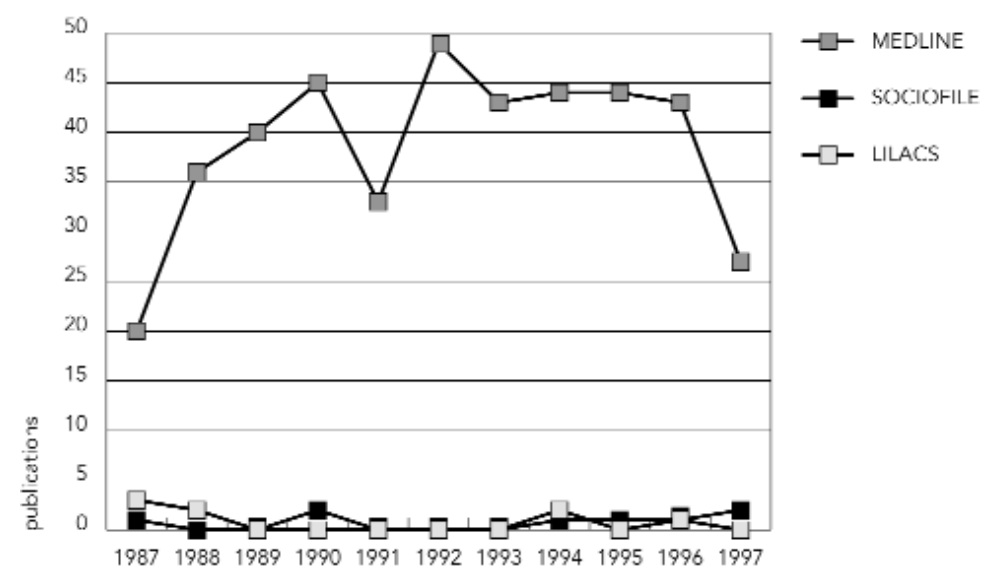




\section{Acknowledgments}

We wish to express our thanks to Fundação de Amparo à Pesquisa do Estado de São Paulo for funding this study, under Proposals 97/08836-6 and 98/01020-3. We would also like to thank the employees of the libraries involved in this research for their prompt and efficient cooperation.

\section{References}

BENET, L. Z., 1997. Principles of prescription order writing and patient compliance instructions. In: The Pharmacological Basis of Therapeutics (A. G. Gilman, T. W. Rall, A. S. Nies \& P. Taylor, eds.), pp. 1697-1705, New York: McGraw-Hill.

BERQUÓ, E., 1996. Algumas considerações demográficas sobre o envelhecimento da população no Brasil. In: Anais do 1o Seminário Internacional sobre Envelhecimento Populacional, pp. 16-34, Brasília: Ministério da Previdência e Assistência Social

COONS, S. J.; SHEAHAN, S. L.; MARTIN, S. S.; HENDRICKS, J.; ROBBINS, C. A. \& JOHNSON, J. A. 1994. Predictors of medication noncompliance in a sample of older adults. Clinical Therapeutics, 16:110-117.

FRATTURA, L.; OSTINO, G.; BORGA, A. D.; D'AMBRÓSIO, R.; MAGGIOROTTI, P.; TODISCO, E.; PRATICHIZZO, W.; PIA, L.; COMELLI, M. \& SPAGNOLI, A., 1989. The elderly and drugs: The possible role of a home visit in improving a "difficult relationship". 1. The results of epidemiologycal study of drug prescription and use by the elderly conducted in the area of local health unit №. 123 in Turin, Italy. Rivista dell'Infermiere, 8:13-23.

GAINSBOROUGH, N. \& POWELL-JACKSON, P., 1990 Prescribing for the elderly. Practitioner, 234: 246249

GIL, A. C., 1994. Métodos e Técnicas de Pesquisa Social. São Paulo: Editora Atlas.

GRYFE, C. L. \& GRYFE, B. M., 1984. Drug therapy of the age: The problem of compliance and the roles of physicians and pharmacists. Journal of the American Geriatrics Society, 32:301-307.

HAYNES, R. B.; McKIBBON, K. A. \& KANANI, R., 1996. Systematic review of randomised trials of interventions to assist patients to follow prescriptions for medications. Lancet, 348:383-386.

HAYNES, R. B., 1979. Introduction. In: Compliance in Health Care (R. B. Haynes, D. L. Sackett \& D. W. Taylor, eds.), pp. 1-7, Baltimore: Johns Hopkins University Press.
IBGE (Fundação Instituto Brasileiro de Geografia e Estatística), 1991. Anuário Estatístico do Brasil: 1996. Rio de Janeiro: IBGE.

JOHNSON, J. A. \& BOOTMAN, J. L., 1995. Drug-related morbidity and mortality. Archives of Internal Medicine, 155:1949-1956.

LAURENTI, R., 1990. Transição demográfica e transição epidemiológica. In: Anais do 1o Congresso Brasileiro de Epidemiologia, pp. 143-165, Rio de Janeiro: ABRASCO.

LEE, M., 1996. Drugs and the elderly: Do you know the risks? American Journal of Nursing, 96:25-33.

NARVAI, P. C., 1997. Produção Científica na Área de Odontologia Preventiva e Social - Brasil, 19861993. Tese de Doutorado, São Paulo: Faculdade de Saúde Pública, Universidade de São Paulo.

OFFERHAUS, L., 1997. Drugs for the Elderly. WHO European Series 71. Geneva: World Health Organization.

OMS (Organización Mundial de la Salud), 1994. Educación Pública Sobre el Uso de los Medicamentos: Una Necesidad Creciente. Boletín de medicamentos esenciales, 18. Ginebra: OMS.

STEWART, R. B. \& CLUFF, L. E., 1972. A review of medication errors and compliance in ambulant patients. Clinical and Pharmacology Therapeutics, 13:463-468.

SULLIVAN, S. D.; KRELING, D. H. \& HAZLET, T. K., 1990. Noncompliance with medication regimens and subsequent hospitalizations: A literature analysis and cost of hospitalization estimate. Journal of Research Pharmaceutical Economic, 2:19-33.

USP/FSP (Universidade de São Paulo/Faculdade de Saúde Pública), 1997. Curso de Acesso às Bases de Dados em CD-ROM MEDLINE e LILACS. São Paulo: Biblioteca/CIR/USP/FSP. (mimeo.)

WILLIAMS, L. \& LOWENTHAL, D. T., 1992. Drug therapy in the elderly. Southern Medical Journal, 85:127-131. 